\title{
Functional categories in the noun phrase: on jacks-of-all-trades and one-trick-ponies in Danish, Dutch and German
}

\begin{abstract}
Dieser Aufsatz behandelt funktional definierte Modifikatorkategorien der Nominalphrase in einigen germanischen Sprachen, insbesondere Dänisch, Niederländisch und Deutsch. Es wird dafür argumentiert, dass funktionale Kategorien, anders als semantische oder formbasierte Kategorien, die einzigen Kategorien sind, die sich einzelsprachlich und übereinzelsprachlich verwenden lassen. Formale Kategorien sind zu eng (sie decken nicht alle strukturellen Varianten ab, die sich übereinzelsprachlich finden) und semantische Kategorien sind zu weit (sie schließen tendentiell zu viele strukturelle Varianten ein). Der Aufsatz befasst sich vor allem mit der Beziehung zwischen Form und Funktion adnominaler Modifikatoren. Während Elemente bestimmter formaler Kategorien (z.B. adNominale PräPositionalPHRaSe oder PP) in verschiedenen Funktionen gebraucht werden können (z.B. als KLASSIFIZIERENDER, QUALIFIZIERENDER oder LOKALISIERENDER/VERANKERNDER MODIFIKATOR des Substantivs), haben andere adnominale Modifikatoren immer die gleiche Funktion. Die vorliegende Untersuchung diskutiert zunächst kurz ein Beispiel eines ,jack-of-all-trades“ im Niederländischen (adnominale PPs mit van, von'), behandelt dann schwerpunktmäßig einen ,one-trickpony“ im Dänischen, das Adjektiv stakkels, arm' (wie in Stakkels pige! ,Armes Mädchen!') und vergleicht dieses mit seinem Übersetzungsäquivalent im Deutschen: arm in Einstellungsausdrücken (z.B. Der arme Junge!).

This paper deals with functionally defined modifier categories of the noun phrase in some Germanic languages, in particular Danish, Dutch and German. It is argued that functional categories, unlike semantic or form-based categories, are the only categories that can be applied within and across languages. Formal categories are too narrow (they do not cover all the structural variants attested across languages) and semantic categories are too wide (they tend to include too many structural variants). The paper is particularly concerned with the relation between form and function of adnominal modifiers. Whereas members of certain formal categories (e.g. ADNOMINAL PREPOSITIONAL PHRASE or PP) can be used in several functions (e.g. as CLASSIFYING, QUALIFYING Or LOCALIZING/ANCHORING MODIFIERS of the noun), other adnominal modifiers always have the same function. The current investigation first briefly discusses an example of a jack-of-all-trades in Dutch (adnominal PPs with van 'of'), then focuses on a one-trick-pony in Danish, the adjective stakkels 'poor' (as in Stakkels pige! 'Poor girl!'), and compares it with its translational counterpart in German: attitudinal arm (e.g. Der arme Junge! 'The poor boy!').
\end{abstract}

\section{Introduction ${ }^{1}$}

We know from everyday life that the same concrete object can serve different functions (for example, a piece of rock can be used as a weapon, a paper weight or a doorstop) and vice versa, that the same function can be performed by different objects (e.g. a sea shell, an empty coconut, a clay pot, the horn of a bovid, a leaf, even cupped hands can all serve as a drinking vessel). On the other hand, there are also objects that can only be used for

\footnotetext{
The notion 'functional category' should NOT be confused with Chomskyan functional categories (i.e. a closed class of elements with a grammatical meaning or function). In this paper, functional categorization is to be contrasted with formal and semantic categorization and relates to the functional approach to grammatical analysis as originally developed by linguists of the Prague School, who were "seeking to understand what jobs the various components were doing [...]" (Sampson 1980, p. 104).
} 
just one task, such as instruments in a physics lab, which are often designed for a highly specific purpose (for example, measuring an electrical current). ${ }^{2}$

The same holds for abstract objects like linguistic forms and constructions. Linguistic expressions (a stem, an affix, a word, a phrase or even larger linguistic units) can often be used in more than one function, and vice versa, different linguistic forms or constructions may do the same job in the process of verbal communication (see examples below). And whereas some linguistic expressions can be used in different functions (like a jack-of-alltrades), other elements are only used in a single function (i.e. they are one-trick-ponies). Cross-linguistic research into part-of-speech systems indicates, for example, that whereas German and many other languages have specialized ('dedicated') word classes (verbs, nouns, adjectives), languages like Samoan and Tongan employ 'all-round words' (the term was coined in Hockett 1958, p. 235), which in their basic form can be used to predicate (verbal function), to refer (nominal function), and to modify (adjectival or adverbial function). ${ }^{3}$

This paper is concerned with the functional modifier categories in the noun phrase and has two main goals (notice that this paper is NOT about functional categories as used in certain syntactocentric theories of grammar; see note 1). Firstly, it wants to argue that functional categories are a truly grammatical phenomenon in that members of a functional category can be characterized in grammatical terms. Secondly, this paper aims to explore the extreme ends of the functionality spectrum (multifunctional vs. monofunctional use of linguistic expressions) with regard to noun modifiers in some modern Germanic languages (Dutch, German, Danish). Since the grammatical properties of a MULTIFUNCTIONAL linguistic construction have already been investigated in a recent publication (Rijkhoff $2009 \mathrm{~b}$; cf. also Zifonun this issue), the current paper mainly focuses on the grammatical characteristics of a noun modifier that is basically MONOFUNCTIONAL, viz. Danish stakkels (as in det stakkels barn 'the poor child', where the speaker expresses sympathy for the referent of the noun phrase) and compares it with its translational counterpart in German, viz. arm (in the sense of attitudinal 'poor').

The paper is organized as follows. Section 2 gives an overview of the functional modifier categories in the noun phrase and explains how they differ from semantic and formal categories. Section 3 discusses the grammatical properties of one particular multifunctional attributive construction in Dutch, adnominal prepositional phrases (PPs) with van 'of', as in een vrouw van 20 (a woman of 20) 'a 20 year old woman', and shows that each function comes with its own set of grammatical properties. Section 4 is a corpus-based investigation of the grammatical properties of one particular monofunctional adnominal modifier in Danish, stakkels 'poor' (expressing sympathy), and the corresponding modifier in German, attitudinal arm 'poor'.

The more general claim of this paper is that functionally defined categories should play a more prominent role in descriptive and theoretical linguistics, in addition to the more or less accepted formal and semantic categories. Apart from the fact that members of the

2 Obviously, any kind of object can be abused, so that one could imagine, for instance, that even the Large Hadron Collider (a.k.a. the Big Bang machine), the world's biggest and highest-energy particle accelerator (intended to collide opposing particle beams) can be used for non-intended purposes.

3 Cf. Mosel and Hovdhaugen (1992, p. 73, 77) on Samoan, and Broschart (1997) on Tongan. See also Nordhoff (2009), who coined the term jack-of-all-trades in the context of flexible word classes. 
same functional category share certain grammatical characteristics (Rijkhoff 2009b), functional categories appear to be the only categories that have universal, cross-linguistic applicability (Rijkhoff 2009a). In other words, any theory of grammar that ignores categories that capture the way(s) linguistic forms and structures are actually used in verbal communication, is incomplete.

\section{Formal, semantic and functional categories}

This section first briefly discusses some problems with formal and semantic categories, the two types of categories that are commonly used in descriptive and theoretical linguistics, arguing that functional categories increase the descriptive and explanatory power of a grammatical theory (sections 2.1-2.3). Section 2.4 presents an overview of functional modifier categories in the noun phrase (with a pointer to their counterparts in the clause), which will serve as a frame of reference for the modifiers discussed in sections 3 and 4. It may be useful to emphasize that there is currently no complete list of functional categories. ${ }^{4}$ This paper should be regarded as an attempt to establish a list of functional modifier categories in the noun phrase and to argue for the employment of usage-based, functional categories in linguistics, alongside the more established semantic and formal categories. ${ }^{5}$

\subsection{Formal and semantic categories: some problems}

Traditionally linguists tend to distinguish two kinds of categories: formal and semantic (or 'conceptual') categories (Haspelmath 2007). Formal categories like Noun Phrase (NP) or Prepositional Phrase (PP) are established on the basis of morphological and syntactic characteristics (Kroeger 2005, p. 26-47; Newmeyer 2007). Thus, formally speaking a PP like 'on the hill' is a unit to which certain syntactic rules of the English grammar apply and which consists of two formally defined components: (i) 'on', a member of the word class PREPOSITION, and (ii) 'the hill', an instance of the formal (phrasal) category NP, which, in its turn, can be further analyzed into smaller components (here: DEFINITE ARTICLE + COMMON NOUN). But since not all languages employ prepositions (or postpositions for that matter), PPs cannot be regarded as a universal category. ${ }^{6}$ Notice furthermore that to the extent that languages can be said to share the same formal categories, the members of these categories do not necessarily share the same formal properties. Thus, whereas in many languages members of the syntactic category NOUN are characterized by the fact that that they can be marked for number, there are also quite a few languages where number marking on the noun is absent (Rijkhoff 2004, p. 45 fn. 28 and p. 146-153).

Semantic categories, on the other hand, are based on 'meaning' rather than 'form' and tend to be preferred by typologists and functional grammarians, mainly because semantic categories are deemed to have cross-linguistic applicability. It appears, however, that semantic categories such as Tense, Comparison, Definiteness or Possession cannot simply be equated across languages either. Whereas formal categories are too narrow in that their defini-

\footnotetext{
Notice that there are also no exhaustive lists of formal and semantic categories.

5 The Theme-Rheme distinction proposed by linguists of the Prague School and Simon Dik's typology of extra-clausal constituents and pragmatic functions (Dik 1997 Part 2, p. 379-407) are examples of earlier attempts to give functional categories a place in modern linguistics.

6 It has even been argued that some languages lack a distinct class of nouns (see above on 'all-round words'), which would suggest that Noun Phrase is not a universal category either (cf. Hengeveld/Rijkhoff 2005, p. 410).
} 
tions do not include all the structural variants attested across languages, semantic categories are often too wide, including too many structural variants to allow for cross-linguistic comparison (for details, see Rijkhoff 2009a).

In sum, the employment of formal and semantic categories poses some serious methodological problems for grammatical theory and linguistic typology. Whereas formal categories are too exclusive in that they do not quite cover all the formal or structural variants that are attested in the languages of the world, semantic categories are on the whole too inclusive, covering too many different forms and constructions to allow for responsible cross-linguistic comparison.

\subsection{Functional categories}

Functional categories are not so much concerned with 'form' or (coded) 'meaning', but rather with the actual job of a linguistic form or construction in the process of verbal (or signed) communication (Rijkhoff 2009a). Although this is sometimes forgotten in the debates between formalist and functionalist schools of linguistics, the idea that linguistic elements should (also) be analyzed from a functional perspective can be traced back at least to linguists of the Prague School in the first half of the 20th century, who were "seeking to understand what jobs the various components were doing [...]" (Sampson 1980, p. 104). ${ }^{7}$ This paper can be seen as an attempt to apply the functionalist approach of the Prague School to current grammatical theory, in particular Simon Dik's Functional GramMAR (Dik 1997) and its successor Functional Discourse Grammar (Hengeveld/Mackenzie 2008). More specifically, I will discuss the five functional modifier categories currently recognized in a 'layered' model of the noun phrase (sections 2.1-2.4.1) as well as a more global functional modifier category, which cross-classifies some of the modifiers accounted for in the layered NP representation: ATTITUDINAL MODIFICATION (section 2.4.2; see also Rijkhoff 2008a, p. 74-77). The latter kind of modification is not associated with a single form or construction, but typically involves a wide range of NP constituents and is expressed simultaneously through e.g. syntax, morphology, and prosody.

\subsection{Functional sameness versus semantic and formal similarity}

Whereas linguistic forms and (coded) meanings are always language specific (and therefore difficult to compare cross-linguistically; see section 2.1), the communicative FUNCTIONS of linguistic expressions in discourse are essentially the same for all languages. For example, one may assume that all languages have elements that can be used in the three basic functions of verbal communication: ${ }^{8}$ (i) to predicate a property of an entity or a relation between entities, (ii) to refer to persons, objects and other entities, and (iii) to modify core linguistic material used in the act of predicating or referring. These elements all belong to one of three major functional categories: Predicate, Referential, Modifier. Certain members of the functional category MoDIFIER are the main topic of this paper. ${ }^{9}$

\footnotetext{
The Prague Linguistic Circle is perhaps best known for the Theme-Rheme distinction and for introducing the concept of 'markedness' in linguists. Currently the theory of Functional Sentence Perspective (FSP), with its focus on communicative dynamism, can be seen as a direct successor of the Prague School of Linguistics (Firbas 1992).

8 See, for instance, Coseriu (1955, 2001), Croft $(1991,2003)$, Lehmann (2008); Ramat (2009) or Sasse (1991).

9 Presumably, the three major functional categories are attested in all languages, but individual languages
} 
Additionally linguistic forms and constructions can be categorized along certain emotional or attitudinal dimensions, as when the form of a linguistic expression reflects the speaker's scorn or sympathy for an entity (usually a person or an animal, but possibly also inanimate and more abstract entities; this is discussed in section 4).

If functional categories are indeed the only truly universal categories in linguistics (i.e. there is FUNCTIONAL SAMENESS across all languages), they should have precedence over formal or semantic categories in cross-linguistic investigations. Subsequently, the members of a functional category may be further classified on the basis of formal or semantic criteria to construct a set of elements that is deemed similar enough to allow for crosslinguistic comparison (i.e. on the basis of FORMAL OR SEMANTIC SIMILARITY within and across languages). It is important to keep in mind, however, that there is often no direct, one-toone relationship between the formal and the functional properties of a linguistic expression. For example, members of the formal category Prepositional Phrase (PP may belong to different functional categories (see Table 3 in section 3). Conversely, members of different formal categories may serve the same function. For example, Table 1 shows that in English members of the formal categories Adjective, Prepositional Phrase and Relative Clause can all serve as a Qualifying ModifiER.

\begin{tabular}{|c|c|c|c|}
\hline \multicolumn{4}{|c|}{ FUNCTIONAL CATEGORY: ADNOMINAL QUALIFYING MODIFIER } \\
\hline SEMANTIC & FORMAL C & ATEGORIES: & \\
\hline CATEGORIES: & ADJECTIVE & PREPOSITIONAL PHRASE & REL. CLAUSE \\
\hline SIZE $\bullet$ & $\operatorname{big} N$ & $N$ of enormous size & $N$ that was rather big \\
\hline VALUE / QUALITY • & expensive $N$ & $N$ of great value & $\ldots$ \\
\hline AGE $\bullet$ & young $N$ & $N$ under age 16 & $\ldots$ \\
\hline COLOR • & $\operatorname{red} N$ & $N$ of incredible redness & $\ldots$ \\
\hline$\ldots \bullet$ & $\ldots$ & $\ldots$ & $\ldots$ \\
\hline
\end{tabular}

Table 1: Formal and semantic subcategories of the functional subcategory, QUALIFYING ModifIER $(\mathrm{N}=$ head noun)

Table 1 also shows that members of the functional subcategory QUALIFYING MODIFIER may belong different semantic categories, such as SIZE ( $a$ big $_{\text {Adj }}$ house, telescopes of enormous size $\left._{\mathrm{PP}}\right)$, VALUE or QUALITY ( a cheap $_{\mathrm{Adj}}$ suit, a pearl of great value $\mathrm{PP}_{\mathrm{PP}}$ ), AGE ( a young $_{\mathrm{Adj}}$ child, youths under age $16_{\mathrm{PP}}$ ), or COLOR (blue ${ }_{\mathrm{Adj}}$ curtains, a Jovian moon of incredible redness $\mathrm{PP}_{\mathrm{PP}}$ ). Since different languages do not necessarily employ the same FORMAL CATEGORIES, we find, for example, that languages without a distinct class of adjectives use verbal or nominal forms (stative verbs, abstract nouns) to express 'adjectival' notions. Thus, Eastern Ojibwa (spoken in North-America) uses verbs to express the property of being tall (Dryer 2008; REL.PX $=$ relativizing prefix).

$$
\begin{array}{ll}
\text { nini } & \text { e-gnoozi-d } \\
\text { man } & \text { REL.PX-tall-3SG } \\
\text { 'a tall man' }
\end{array}
$$

may differ with regard to the use of (functional, semantic or formal) subcategories that are employed (see Table 1). 
Similarly, not all languages share the same set of SEMANTIC CATEGORIES. For example, Everett (2005, p. 627-628) claims that there are no color terms in the South-American language Pirahã (see also Dixon 1982 on the absence of certain semantic categories in specific languages).

\subsection{Functional modifier categories in the noun phrase}

This section gives a very brief overview of the adnominal functional modifier categories that have recently been proposed: (i) CLASSIFYING MODIFIERS, (ii) QUALIFYING MODIFIERS, (iii) QUANTIFYING MODIFIERS, (iv) LOCALIZING/ANCHORING MODIFIERS, and (v) DISCOURSE-REFERENTIAL MODIFIERS. In a schematic, 'layered' model of the noun phrase (NP), which captures differences in semantic scope, adnominal modifiers are distributed over five nested layers. The notion 'adnominal modifier' covers both grammatical (e.g. article, demonstrative) and lexical (e.g. adjective, adpositional phrase, relative clause) instances of noun modifiers in an integral, 'whole' noun phrase and includes all dependents of the noun that are not arguments or complements.

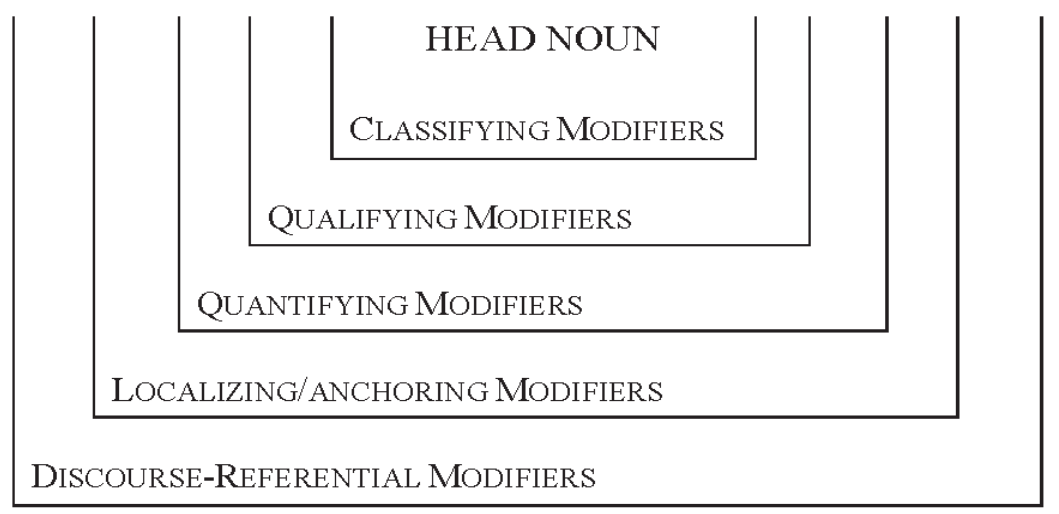

Figure 1: Functional modifiers in a layered representation of NP structure, reflecting scopal differences between the modifier categories.

Due to space limitations, I will assume familiarity with the layered representation of noun phrase structure and not provide evidence and arguments for this analysis here (for a detailed presentation, the reader is referred to Rijkhoff (2008a-c, 2010), which also discusses parallels between the layered organization of NPs and clauses). Notice that the more encompassing ATTITUDINAL modifier categories are not captured in Figure 1 (this is explained in section 2).

\subsubsection{Layers of modification in the noun phrase}

Currently the layered NP-model accomodates five functional modifier categories, which (as was already noted above) cover both grammatical and lexical modifiers (Figure 1). Classifying modifiers further specify what kind of entity the speaker is referring to. For example, if a language has a class of (derived) adjectives, the category of classifying modifiers typically includes so-called relational adjectives, such as musical in musical instrument, or, for that matter, relational in relational adjective (Warren 1984; Gunkel and Zifonun 2009). The range of semantic subcategories covered by members of the functional category of classifying modifiers is rather wide and includes, among others: MATERIAL, PURPOSE, STATUS and RANK, ORIGIN, and MODE OF OPERATION (Halliday 2004, p. 320). 
Qualifying modifiers specify more or less inherent properties of the referent of the NP and have scope over the layer that accommodates classifying modifiers. The major semantic categories that are typically covered by qualifying modifiers are (Dixon 1982): DIMENSION (big, long, etc.), PHYSICAL PROPERTY (hard, heavy, COLOR (black, blue), HUMAN PROPENSITY (jealous, sad), AGE (new, old), value (good, atrocious) and SPEED (slow, fast). These properties are most typically specified by adjectives (if a language has them), but also by relative clauses headed by a stative verb (see example from Eastern Ojibwa above) or possessives headed by an abstract noun (Rijkhoff 2004, p. 133-141; Rijkhoff 2008a; Gil 2009).

The quantity layer has scope over modifiers in the quality layer and accommodates modifiers having to do with number distinctions (singular, plural) and cardinality (one, two, etc.).

Localizing/anchoring modifiers indicate properties concerning the location of the referent of the NP and have scope over the quantity layer (see also Seiler 1978, 1985). Since localizing modifiers basically serve to make the referent of the matrix NP identifiable for the addressee, they normally occur in definite NPs. The most straightforward examples of adnominal localizing modifiers are demonstratives (German dieses Haus 'this house') and PPs specifying the spatial location of the referent of the matrix NP (German das Haus auf dem Hïgel 'the house on the hill'). Possessives indicating ownership and restrictive relative clauses are often used in a localizing function, as they appear to be excellent vehicles for REFERENTIAL ANCHORS, which make it possible to identify the otherwise unidentifiable referent of the matrix NP (Rijkhoff 2004, p. 173-178) - hence the alternative label 'anchoring modifier'.

Modifiers represented in the discourse-referential layer have the widest scope and are concerned with the interpersonal status of the referent of the NP in the shared world of discourse (a mental construct). ${ }^{10}$ Discourse-referential modifiers relate to the referential or existential status of an entity (e.g. object or event) in the world of discourse created by the participants of a speech event. Definite and indefinite articles are good examples of discourse-referential modifiers. By using a definite article, the speaker signals that the addressee is presumed to be familiar with the existence of the referent of the NP in conversational space or that the addressee will be able to identify the referent in conversational space. Conversely, by using an indefinite article, the speaker indicates that the addressee is not expected to identify the referent.

\subsubsection{Modification beyond layering: expressing sympathy or scorn}

So far we have dealt with instances of modification that can be represented in a layered structure, which is based on scopal (hierarchical) relations that hold between members of the various modifier categories (Figure 1). However, there is also a kind of modification that cannot be properly captured in a layered representation of NP structure. This concerns expressions through which the speaker explicitly expresses SYMPATHY or SCORN for the referent. For example, German $d u$ armes Kind ('you poor child') does not refer to a pen-

10 Here 'interpersonal' is used in the Hallidayan sense, covering both subjective and intersubjective meanings (cf. Lyons 1982, p. 102, Lyons 1994; Traugott 2003, 2005). More specifically 'interpersonal' refers to the way in which natural languages provide for the speaker's expression of his/her attitude with regard to the situation, attitudes or beliefs of the addressee $\left(2^{\text {nd }}\right.$ person $)$ or some other referent $\left(1^{\text {st }}\right.$ or $3^{\text {rd }}$ person). 
niless child, but rather to a child who in the speaker's opinion deserves one's sympathy. Even though from a non-attitudinal perspective elements like German arm seem to have the same scope as qualifying modifiers when they serve to indicate the speaker's or writer's sympathetic attitude towards the referent of the noun phrase, they have a number of special properties that set them apart from the modifier categories in the layered representation (Figure 1). ${ }^{11}$ In other words, a modifier may be classified by two modifier categories: apart from being a member of a non-attitudinal modifier category (as captured in the layered model of the NP), they can also be part of a larger, more encompassing expression device (as shown in example (2) below), when the NP they appear in is also used to communicate the speaker's emotional attitude towards an entity.

Perhaps the most important difference between attitudinal and non-attitudinal forms of modification is that speaker attitudes like sympathy or scorn do not reside in just a single modifier such as arm 'poor', but rather manifest themselves simultaneously in a variety of ways (morpho-syntactically, prosodically, in voice quality) as a property of a whole construction (Halliday 2004, p. 61, 238, 318/9, see also sections 4.2 and 4.3). This is shown in the following example from Dutch, where scorn is expressed morpho-syntactically through the use of a distal demonstrative $d a t$ 'that' the diminutive suffix -je and the postnominal possessive construction van jou 'of you' (Rijkhoff 2008a, p. 76-77):

$$
\begin{aligned}
& \text { Ik vind dat nieuwe boek-je van jou helemaal niks } \\
& \text { I find that new book-DIM of you totally nothing } \\
& \text { 'I do not think much of that new book (lit. 'booklet') of yours' }
\end{aligned}
$$

The extra, attitudinal value of the NP is absent without the diminutive and the proximal form of the demonstrative and with the pre-nominal variant of the possessive modifier instead of the post-nominal one.

(3) Ik vind je nieuwe boek helemaal niks (unmarked alternative)

I find your new book absolutely nothing

'I do not think much of your latest book'

Example (2) shows that, strictly speaking, it would be wrong to use the label 'attitudinal modifier', as attitudes like SYMPATHY or SCORN are not expressed through a single modifier but rather manifest themselves in various ways across the whole NP. Nevertheless, we can say that the expression of attitudinal categories is strongly associated with certain modifiers, in that languages may have a group of more or less 'dedicated' (i.e. monofunctional) modifiers, which only appear in a noun phrase that is used when the speaker wants to express SyMPATHY or SCORN for the referent of that noun phrase.

In Dutch, German and many other languages 'attitudinal modifiers' like arm 'poor' have other meanings (e.g. 'penniless') when they appear in a NP that is unmarked for the speaker's attitude. ${ }^{12}$ Danish, on the other hand, has a modifier that only appears in NPs that are marked for some attitudinal value. For the sake of convenience we will call adjectives

11 See, for example, Clark/Clark (1977, p. 474) and Seiler (1978) on the relative order of 'stacked' qualifying adjectives (more references on this topic are provided in Rijkhoff 2004, S. 218 fn.7). Notice that the relative order is which these adjectives precede or follow the head noun also appears to reflect differences in semantic scope, with adjectives specifying more external or subjective properties normally occurring further away from the head than adjectives specifying internal or objective properties (Rijkhoff 2008a, p. 75). Compare, for example, two BEAUTIFUL BIG RED cats vs. ? two RED BEAUTIFUL BIG cats.

12 But notice that Dutch and German do have a dedicated set of words to express scorn (i.e. swear words). 
that appear in such attitudinally modified NPs 'attitudinal modifiers', but so as to remind ourselves that this name is only used for reasons of convenience, it will continue to appear in single quote marks (section 4).

\section{One form - many functions: adnominal prepositional phrases with Dutch van 'of'.}

It was already mentioned in section 2.3 that members of the same formal category may belong to different functional categories. For example, adjectives can be used in a classifying function (e.g. presidential in presidential election) or in a qualifying function (e.g. popular in popular song). Some adjectives can even be used in both functions. A wellknown example is the adjective social, which is a classifying modifier in social security and a qualifying modifier in social person. Another example is criminal lawyer, which either refers to a lawyer who is also a criminal (i.e. the adjective is a qualifying modifier) or to a kind of lawyer, viz. a lawyer who represents persons who have been charged with a crime and argues their cases in courts of law (i.e. the adjective is a classifying modifier). This section focuses on the range of modifier functions of members of one particular formal category: Dutch prepositional phrases with van 'of'. It will be shown how the grammatical properties of this phrase correlate directly with the kind of modifier function it has in the noun phrase.

Dutch adnominal prepositional phrases with van 'of' can occur in at least three different functions. They can be used as a classifying modifier, as a qualifying modifier, or as a localizing modifier $(\mathrm{N}=$ neuter gender; $\mathrm{C}=$ common gender $)$ :

$$
\begin{array}{llll}
\text { een man van het toneel [CLASSIFYING MODIFIER] } & \begin{array}{l}
\text { the } \\
\text { stage }^{13}
\end{array} \\
\text { a man of the } & & \\
\text { 'an actor' (esp. a dedicated actor) } & \\
\text { een kroon van goud } & \text { [QUALIFYING MODIFIER] } \\
\text { a crown of } & \begin{array}{l}
\text { gold } \\
\text { 'a crown of gold' }
\end{array}
\end{array}
$$

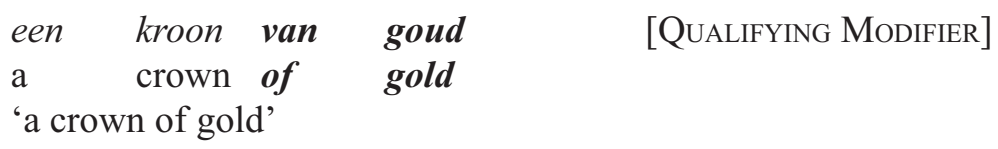

Table 2 shows that each modifier function of this construction correlates with a different set of values for three parameters:

- Modification: the head noun of the noun phrase in the PP can itself be modified (i.e. internal modification)

- Predication: the PP can occur in predicate position

- REFERENCE: the noun phrase in the PP is referential (i.e. the NP refers to a particular entity).

13 Examples are easily found, for instance: Als een man van het toneel zoek ik altijd naar manieren om uit te drukken wat niet wordt gezegd "As a man of the stage, I am always looking for ways to express what is not being said' (from a review of Joshua Sobol's novel 'Silence' in the Dutch newspaper Trouw of 11 October 2002); web address http://www.trouw.nl/krantenarchief/2002/10/11/2126951/Vechten_tegen_ het_vergeten.html 


\begin{tabular}{|l|l|l|l|}
\hline $\begin{array}{l}\text { ADNOMINAL } \\
\text { PPS WITH } V A N \text { 'OF' }\end{array}$ & MODIFICATION & PREDICATION & REFERENCE \\
\hline $\begin{array}{l}\text { LOCALIZING } \\
\text { de auto van de man } \\
\text { the car of the man } \\
\text { 'the man's car' }\end{array}$ & $\begin{array}{l}\text { de auto van de oude man } \\
\text { 'the car of the old man' }\end{array}$ & $\begin{array}{l}\text { de auto is van de man } \\
\text { the car is of the man } \\
\text { 'the car belongs to the man' }\end{array}$ & $\begin{array}{l}\text { de auto van die man } \\
\text { the car of that man } \\
\text { 'that man's car' }\end{array}$ \\
\hline $\begin{array}{l}\text { QUALIFYING B } \\
\text { een kroon van goud } \\
\text { 'a crown of gold' }\end{array}$ & $\begin{array}{l}\text { een kroon van zuiver goud } \\
\text { 'a crown of pure gold' }\end{array}$ & $\begin{array}{l}\text { de kroon is van goud } \\
\text { the crown is of gold } \\
\text { 'the crown is made of gold' }\end{array}$ & - \\
\hline $\begin{array}{l}\text { QUALIFYING A } \\
\text { een man van gezag } \\
\text { 'a man of authority' }\end{array}$ & $\begin{array}{l}\text { een man van groot gezag } \\
\text { 'a man of great authority' }\end{array}$ & - & - \\
\hline $\begin{array}{l}\text { CLASSIFYING } \\
\text { een man van het toneel } \\
\text { 'a man of the stage' }\end{array}$ & - & - & - \\
\hline
\end{tabular}

Table 2: Properties of classifying, qualifying and localizing prepositional phrases with van 'of' in Dutch.

Notice that qualifying PPs with van 'of' come in two varieties: those that allow both Modification and Predication (Qualifying B) and those that only permit Modification (Qualifying A). A more detailed overview of the functions of prepositional phrases with van 'of' in Dutch is presented in Rijkhoff (2009b, p. 91-94), which shows that PPs of types Qualifying A and Qualifying B can be further divided into (i) a subtype with an optional internal modifier (shown in Table 2) and (ii) a subtype with a compulsory internal modifier.

Adnominal PP with van 'of': Qualifying Type B with a compulsory internal modifier:

$\begin{array}{lll}\text { beelden van grote } & \text { kwaliteit (vs. * beelden van kwaliteit) } \\ \text { statues of } & \text { great } & \text { quality } \\ \text { 'statues of high quality' } & \end{array}$

Adnominal PP with van 'of': Qualifying Type A with a compulsory internal modifier:

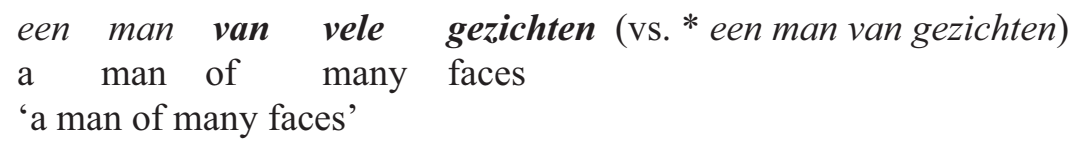

The same study also argues that it is probably more realistic to regard the various modifier types as reference points on a scale of noun modification rather than distinct modifier classes (cf. Seiler 1985), as it is sometimes rather difficult to draw a clear line between the various types of adnominal possessives.

In the current section we have been concerned with the multifunctional character of Dutch attributive PPs with van 'of'. The next section deals with a modifier that is almost exclusively used in a single function: the Danish modifier stakkels 'poor'. 


\section{A corpus-based study of a one-trick-pony: Danish adnominal stakkels 'poor' (with comparative data on German attitudinal $\mathrm{arm}$ )}

The Danish modifier stakkels 'poor' translates into German as the attitudinal adjective arm, i.e. in the sense of bedauernswert or unglücklich (Das Digitale Wörterbuch der Deutschen Sprache des 20. Jahrhundert - (http://www.dwds.de/)). ${ }^{14}$ Other meanings of arm are (i) ohne Geld 'penniless' and (ii) ohne Nutzgehalt, kärglich 'without content or real substance'. As mentioned above, Danish stakkels differs from German arm and English poor in that its occurrence is confined to NPs that the speaker (also) uses to express his or her sympathy for the referent, as in stakkels Jens 'poor Jens'..$^{15}$ The current paper is only concerned with stakkels as an adnominal modifier, which accounts for nearly all of its occurrences in Korpus DK. This 56 million-word corpus of written Danish contains roughly 1200 tokens of the adjective stakkels, but only in half a dozen instances $(0.5 \%)$ stakkels serves as a predicate rather than a modifier, as in:

$\begin{array}{llll}\text { Jeg er aldeles } & \text { ikke } & \text { stakkels } \\ \text { I am absolutely not } & \text { pitiable } \\ \text { 'I am not pitiful at all' } & & \end{array}$

\begin{tabular}{|c|c|c|c|c|c|c|c|c|}
\hline $\begin{array}{l}\text { Røvere } \\
\text { Robbers }\end{array}$ & $\begin{array}{l}e r \\
\text { are }\end{array}$ & $\begin{array}{l}\text { også } \\
\text { also }\end{array}$ & $\begin{array}{l}\text { menneske } \\
\text { persons, }\end{array}$ & & $\begin{array}{l}o g \\
\text { and }\end{array}$ & $\begin{array}{l}\text { mere } \\
\text { more }\end{array}$ & $\begin{array}{l}\text { stakkels end } \\
\text { pitiable than }\end{array}$ & $\begin{array}{l}\text { os, } \\
\text { us, }\end{array}$ \\
\hline $\begin{array}{l}\text { hvis } \\
\text { if }\end{array}$ & $\begin{array}{l}\text { de } \\
\text { they }\end{array}$ & $\begin{array}{l}\text { røver } \\
\text { steal }\end{array}$ & $\begin{array}{l}\text { af } \\
\text { of }\end{array}$ & $\begin{array}{l}n ø d^{16} \\
\text { necessi }\end{array}$ & & & & \\
\hline
\end{tabular}

Notice that the six predicative cases include two occurrences in which stakkels is used in an exclamation: (i) Stakkels de amerikanske spillere 'Take pity on the American players', 'Poor American players' and (ii) Stakkels de mennesker, der er rige 'Pity the people who are rich'.

This section shows that modifiers such as Danish stakkels and German (attitudinal) arm display a number of special grammatical properties, which can be directly attributed to the fact that they appear in an attitudinally modified NP. We will focus on three grammatical features of stakkels and arm that are deemed particularly characteristic for 'attitudinal modifiers' (see above on the shorthand character of this label) in that they clearly reflect their special, interpersonal character. Unlike members of other modifier categories in the NP, 'attitudinal modifiers'

- are also used to modify personal pronouns (e.g. Stakkels dig 'Poor you', section 4.1);

- have a strong tendency to occur with certain adjectives (like 'little', 'young' or 'innocent') and nouns (e.g. Danish pige 'girl' or barn 'child'), i.e. they select a special set of COLLOCATES), which is another indication that 'attitudinal modification' cannot be reduced to the employment of a member of a single modifier category, but should

14 The Danish adjective arm also means 'poor' in the attitudinal sense, but this adjective also has other meanings, just like English poor and German arm. In Danish, arm is considered to have a stronger meaning than stakkels, which is the unmarked choice in everyday speech.

15 Stakkels is never used in the sense of 'having little money or possessions' and I found only one example where stakkels was used to indicate an insufficient or insignificant quality or amount: stakkels 12 kroner 'a meager 12 Danish crowns'.

16 This is the only occurence of stakkels in the comparative (the corpus has no instances of the superlative). 
rather be regarded as a property of the whole NP (e.g. stakkels uskyldigt barn 'poor innocent child', section 4.2);

- tend to occur in specific syntactic environments, especially in more or less freestanding or independent units such as (i) exclamations (Arme Frau! 'Poor woman!'), (ii) appositions (wir armen Frauen 'we poor women') or (iii) dislocated phrases (Hatte immer Schwierigkeiten in der Schule, der arme Kerl 'Always had trouble in school, the poor fellow', section 4.3).

\subsection{Types of nominal heads modified by Danish stakkels and German (attitudinal)} arm

Modifiers like Danish stakkels or English poor combine with three types of head constituents (see below in German arm): personal pronouns, proper nouns, and common nouns. ${ }^{17}$ Table 3 and 4 give the frequencies of stakkels and arm in the different modifier-head combinations in KorpusDK (Danish) and DWDS-Kerncorpus (German); notice that the figures only refer to cases where the modifier in question immediately precedes the head. ${ }^{18}$

\begin{tabular}{|c|c|c|}
\hline \multicolumn{3}{|c|}{ stakkels in KorpusDK (36 million words): total $=907$} \\
\hline $\begin{array}{c}\text { stakkels + pers.pronoun: } \\
\mathbf{1 . 4} \%(\mathrm{n}=13)\end{array}$ & $\begin{array}{c}\text { stakkels + proper name: } \\
\mathbf{2 4} \%(\mathrm{n}=218)\end{array}$ & $\begin{array}{c}\text { stakkels + common noun: } \\
\mathbf{7 4 . 6} \%(\mathrm{n}=676)\end{array}$ \\
\hline $\begin{array}{l}\text { example: } \\
\text { stakkels dig 'poor you' }\end{array}$ & $\begin{array}{l}\text { example: } \\
\text { stakkels Emil 'poor Emil' }\end{array}$ & $\begin{array}{l}\text { example: } \\
\text { stakkels barn 'poor child' }\end{array}$ \\
\hline
\end{tabular}

Table 3: Danish stakkels with different types of head constituents

\begin{tabular}{|c|c|c|}
\hline \multicolumn{3}{|c|}{ arm in DWDS-Kerncorpus (100 million words): total $=5914$} \\
\hline $\begin{array}{l}\text { arm }+ \text { pers.pronoun: } \\
\quad \mathbf{0} \% \\
\text { (instead we find e.g. } \\
\text { du Armer 'poor you'; } \\
\text { see below) }\end{array}$ & $\begin{array}{l}\qquad a r m+\text { proper name: } \\
\qquad \mathbf{8 . 8} \%(\mathrm{n}=522) \\
\text { example: } \\
\text { die arme Sophie 'poor Sophie' }\end{array}$ & $\begin{array}{l}\text { arm + common noun: } \\
\qquad \mathbf{9 1 . 2} \%(\mathrm{n}=5392) \\
\text { example: } \\
\text { die arme Seele 'the poor soul' }\end{array}$ \\
\hline
\end{tabular}

Table 4: German arm with different types of head constituents

Both in Danish and in German the 'attitudinal modifier' under investigation is most frequently attested in combination with a common noun. The main reason why stakkels occurs less often as a modifier of common nouns than arm is that we have not yet distinguished between attitudinal and non-attitudinal uses of arm in Table 4 (it is not possible to query different senses of a particular word or lexeme in DWDS-Kerncorpus). This is done in section 4.2, where we will also take a closer look at its most frequent collocates.

17 Stakkels is apparently related to the Danish noun stakkel 'beggar, person to feel sorry for', which can be traced to North-Germanic (Old Norwegian) stafkarl (lit. stick man) 'beggar who wanders around with a stick (staf) in his hand; cf. De Vries (1997, p. 690) on the Dutch noun stakker(d)). The two forms even occur together as in den stakkels stakkel 'the poor sod' (from an article in the newspaper Politiken, 2 May 2000).

18 Detailed information about the composition of the two corpora can be found at: http://ordnet.dk/korpusdk_en/front-page/view?set_language=en and http://www.dwds.de/textbasis/kerncorpus. 


\subsubsection{Head constituent is a personal pronoun}

The fact that stakkels can modify personal pronouns (see below on arm in combination with a personal pronoun) is a clear indication of its attitudinal function: given their interpersonal nature, personal pronouns may be expected to take only 'attitudinal (interpersonal) modifiers' (Butler 2008, p. 244). KorpusDK contains 13 examples of a personal pronoun modified by stakkels and the data suggest that there is a distinct preference for NON-FIRST PERSON PRONOUNS (11 occurrences of $2^{\text {nd }}$ and $3^{\text {rd }}$ person pronouns), as in: ${ }^{19}$

$\begin{array}{lll}\text { Stakkels } & \text { dig, } \quad \text { sagde han } \\ \text { poor } & \text { you:OBJ said } & \text { he } \\ \text { 'Poor } & \text { you, he said' } & \end{array}$

$\begin{array}{lll}\text { Han skulle på arbejde. Stakkels ham. } & \begin{array}{l}\text { Ste } \\ \text { he should on work. }\end{array} \\ \text { 'He had to go to work. Poor him', } & & \text { him }\end{array}$

Interestingly, an investigation of the DWDS-Kerncorpus, which also includes a small selection of spoken language ( $5 \%$ of the total corpus), did not produce a single clear example of a personal pronoun being modified by attitudinal $\mathrm{arm} \cdot{ }^{20}$ Instead we found some 35 instances of a construction in which a first or second person pronoun precedes Arme "poor one' or one of its inflectional variants (such as Armes, Ärmste or Ärmster), i.e. in German we find a preference for NON-THIRD PERSON PRONOUNS. ${ }^{21}$

(13) "Du Armer," hatte sie gerufen, "du kannst überfahren werden."
you poor_one had she called you can run over become [talking to a dog] "“Poor you", she had shouted, "you could be run over (by a car)."

$$
\begin{aligned}
& \text { Meinen Sie ... wirklich, Sie Ärmster, } \\
& \text { mean you ... really you poorest_one } \\
& \text { 'Do you really mean ..., (lit.) poorest you,' (notice that Sie is here the polite form of address] }
\end{aligned}
$$

These constructions are mainly used to refer to the addressee, involving either plain $d u(d u$ Arme, du Armer, du Armes, du Ärmste, du Ärmster, du Ärmstes) or the polite form Sie (Sie Ärmste, Sie Ärmster). The other occurrences concern references to the speaker (singular or plural): ich Arme, mir Armen, mich Arme, wir Armen, wir Armsten. ${ }^{22}$ However, since this

19 Butler (2008, p. 244) found 23 occurrences of the combination 'poor' plus personal pronoun in the British National Corpus (100 million words with more than 15.000 occurrences of 'poor' in all its senses): 12 instances of 'me' and 11 occurrences of 'you'. The senses of English 'poor' are similar to those of German arm: (i) 'having little money or possessions', (ii) 'of a quality/amount/etc. which is lower than desirable/expected', and (iii) the interpersonal use, to express sympathy. On the use of poor with proper names and pronouns, see e.g. Huddleston and Pullum (2002, p. 430, 520), Biber et al. (1999, p. 509f.).

20 A search in the German corpus only produced one example of attitudinal arm modifying a personal pronoun, but this involved a nominalized form of the pronoun (das Ich 'the I/EGO'; emphasis mine - JR): "Ihm war das Kind die wunderbare Erhöhung, die, über das eigene, arme Ich, der Vollkommenheit näher rückt, - und sein Begehren, ein Kind lieben zu dürfen, war so stark, daß er oftmals glaubte, ohne diese Liebe nicht leben zu können.” (Grete Meisel-Hess. 1911. Die Intellektuellen. Berlin: Oesterheld).

21 Notice that there is an alternative construction for third person referents without a personal pronoun but with a definite determiner: der Arme, die Arme, die Armen, etc.

22 The only deviant case involves a non-first person form that is used to refer to the speaker (emphasis mine; notice that the English phrases are part of the original text - JR): "Würde sie es dann gestatten und hätte sie nichts dagegen, so würde er, - Daniel Horatio, - sich irgendwo in der Nähe niederlassen und ebenfalls die Reize des südlichen Frühlings genießen. Wenn sie ihn Ärmsten nicht vergessen habe, - if 
does not involve the modifier arm, this particular construction will not be discussed any further here.

\subsubsection{Head constituent is a proper name}

In many languages a proper name can be modified by an 'attitudinal attribute' (meine süße Anna 'my sweet Anna') or a 'non-attitudinal attribute' (der dicke Peter '[the] fat Peter'). Interestingly, only 'attitudinal attributes' like arm 'poor', lieb 'dear' or süß 'sweet' may occur before a proper name in certain syntactic environments, such as exclamations (cf. Poor John! vs. *Rich John!) or certain forms of address ( "Ach, liebste Johanna", antwortete er 'Oh dearest Johanna, he answered' vs. * "Ach, reichste Johanna”, antwortete er more on syntactic environments in section 4.3). ${ }^{23}$ In English proper nouns constitute a very large group of head constituents that are modified by attitudinal poor (Butler 2008, p. 244) and the same is true for stakkels and (to a lesser extent) arm. In Danish we find that stakkels precedes a proper name in nearly 25 percent of the cases, as in stakkels Søren 'poor Søren'. Although this type of head constituent mainly includes names for human beings, it also contains names for a rather wide variety of other entity types, such as pets and other animals (stakkels hund 'poor dog', stakkels gris 'poor pig'), cities (stakkels Aarhus), countries (stakkels Cambodja, stakkels Danmark), regions (stakkels Balkan), cars (stakkels Trabant 'poor Trabant') and even beer companies (stakkels Carlsberg).

By contrast, attitudinal arm is almost exclusively used with proper names of persons, which furthermore require a definite article (not, however, in an exclamation).

$\begin{array}{llllll}\text { Der arme Theo, ich habe ihn so } & \text { gepeinigt }{ }^{24} \\ \text { the poor Theo I } & \text { have him } & \text { so } & \text { caused_pain }\end{array}$

'Poor Theo, I have hurt him so much'

DWDS-Kerncorpus contains 522 instances of attitudinal arm directly preceding a proper name $(8.85 \%)$ and in the very few cases where it does not modify a person's name, it concerns the name of a country or a city:
Es geht
it goes
eine
Woge
von
Sentimentalität
durch das
Land:
it goes a
wave of sentimentality
through the country

you have not forgotten poor me, - dann möge sie ihm doch ein Kabeltelegramm senden, - ein Ja oder ein Nein. Sei es ein Ja, - which would bring the happiest hour of my life, - so würde sie umgehend weitere telegraphische Nachrichten von ihm erhalten." (Grete Meisel-Hess (1911): Die Intellektuellen. Berlin).

23 In this respect, there are interesting differences between the various languages. For example, the German corpus contains several instances of proper names being modified by a 'non-attitudinal adjective' (usually from the same small set with e.g. groß 'big, tall', klein 'small', heilig 'holy', tapfer 'brave', treu 'loyal, faithful'), whereas in Dutch such combinations typically only occur as a complex name (Lange Jan 'Tall John'). Perhaps this difference is due to the fact that in German (der Peter) but not in Dutch (*de Peter) a proper name has to appear with a determiner. Interestingly, proper names in Dutch can be modified by an adjective if the phrase also contains a determiner (from the Internet): Is dat niet de beruchte 'dr.' Hong Zhou? 'Isn't that the notorious 'dr' Hong Zhou?'. This suggests that the reason why in German but not in Dutch proper names can be modified by an adjective (in the default case) seems to be that German proper names normally appear in a syntactic frame that also contains slots for certain modifiers, whereas proper names in Dutch commonly appear in a syntactic frame that does not provide slots for modifiers. Obviously this is a topic that requires a much more detailed investigation.

24 From: Hedwig Dohm (1902): Christa Ruland. Leipzig: List. 
Das arme Abessinien!

the poor Abyssinia

'A wave of sentimentality sweeps through the country: poor Abyssinia!'

Thus, to the extent that the figures given above are reliable, Danish stakkels appears to be used in combination with a proper name approximately three times $(24.4 \%)$ more often than German arm (8.8\%)

\subsection{Danish stakkels and German arm: collocates}

One of the properties that set 'attitudinal modifiers' apart from other modifiers is their tendency to occur with a very specific set of adjectives and nouns. Since the collocation tool in KorpusDK appears to be fixed for an interval of maximally two intervening words, we specified the same interval for collocates of arm in the DWDS-Kerncorpus. Furthermore, it turned out that the collocation tool of DWDS-Kerncorpus uses lemmas for both arm and its collocates, whereas the collocation tool of KorpusDK only uses the lemma of stakkels (which was not relevant here, as we are only interested in the modifier, which is morphologically invariant), but finds and lists the collocates on the basis of word forms. Here are, for example, the 20 occurrences of the collocate dreng 'boy' generated by KorpusDK; notice that the list does not contain any inflected form of dreng.

(17) Min stakkels dreng

Den stakkels dreng

Den stakkels dreng

Den stakkels dreng

Stakkels dreng!

den stakkels dreng

en stakkels dreng

Stakkels dreng.

den stakkels dreng

Den stakkels dreng

den stakkels dreng

den stakkels dreng

Stakkels dreng

stakkels dreng

Stakkels dreng!

stakkels dreng

den stakkels dreng

den stakkels dreng

den stakkels dreng

den stakkels voldelige dreng

Now compare the collocation results from KorpusDK with some collocates of arm produced by DWDS-Kerncorpus, which does include inflected forms.

(18) (die Enttäuschung) des armen Jungen

Der arme Junge, dem armen Junge

ein armer dummer Jung

der Freude des armen Jungen. 
So as to be able to compare the collocation lists of stakkels and (attitudinal) arm, we put together all the word collocates of stakkels sharing the same lemma to produce a new, lemma-based list of the ten most frequent collocates. This meant, for example, that three more occurrences were added to the list of twenty occurrences in (17): (i) de stakkels drenge 'the poor boys', (ii) mine to stakkels drenge 'my two poor boys', (iii) stakkels drenge 'poor boys'. This new, lemma-based list was then used to compare collocates of stakkels (Table 5) with collocates of attitudinal arm (Table 7).

\begin{tabular}{|c|c|c|c|c|}
\hline N [LEMMA] & $\begin{array}{l}\text { STAKKELS +N: } \\
\text { NR. OF TOKENS }\end{array}$ & $\mathrm{N}$ [LEMMA] & \multicolumn{2}{|c|}{$\begin{array}{c}\text { PROPORTION OF N } \\
\text { MODIFIED BY STAKKELS }\end{array}$} \\
\hline mand 'man, husband' & 70 & pige & $47 / 19400$ & $0.24 \%$ \\
\hline menneske 'person' & 55 & fyr & $8 / 3538$ & $0.23 \%$ \\
\hline barn 'child' & 48 & \multirow{2}{*}{$\begin{array}{l}d y r \\
\text { mand }\end{array}$} & $22 / 16690$ & $0.13 \%$ \\
\hline pige 'girl' & 47 & & $70 / 54632$ & $0.13 \%$ \\
\hline kvinde 'woman' & 24 & \multirow{2}{*}{ dreng } & \multirow{2}{*}{$23 / 13060$} & \multirow{2}{*}{$0.12 \%$} \\
\hline dreng 'boy' & 23 & & & \\
\hline$d y r$ 'animal' & 22 & $\begin{array}{l}\text { menneske } \\
\text { kone }\end{array}$ & $\begin{array}{c}55 / 47963 \\
9 / 8155\end{array}$ & $\begin{array}{l}0.11 \% \\
0.11 \%\end{array}$ \\
\hline mor 'mother' & 17 & \multirow{2}{*}{$\begin{array}{l}\text { mor } \\
\text { barn }\end{array}$} & $17 / 21954$ & $0.08 \%$ \\
\hline kone 'wife' & 9 & & $48 / 63452$ & $0.08 \%$ \\
\hline fyr 'guy' & 8 & kvinde & $24 / 32843$ & $0.07 \%$ \\
\hline
\end{tabular}

Table 5: The 10 most frequent nominal collocates of stakkels 'poor' in KorpusDK. ${ }^{25}$

In the case of German, it is necessary to first separate attitudinal occurrences of arm from the instances where arm does not occur in an attitudinally modified NP. Table 6 gives the distribution of the adnominal adjective $\mathrm{arm}$ as a modifier of its most frequent collocates in DWDS-Kerncorpus. Figures in round brackets indicate the total number of occurrences in the corpus, whereas the non-bracketed figures specify the number of occurrences that could actually be investigated ("anzeigbar aufgrund rechtlicher Nutzungsvereinbarungen") and which will be used further below.

\begin{tabular}{|l|c|c|cc|}
\hline N [LEMMA] & $\begin{array}{c}\text { NUMBER OF } \\
\text { TOKENS } \\
\text { (RAW DATA) }\end{array}$ & $\begin{array}{c}\text { NUMBER OF } \\
\text { OCCURRENCES OF } \\
\text { ARM+ N } \\
\text { (RAWDATA) }\end{array}$ & \multicolumn{2}{|c|}{$\begin{array}{c}\text { PROPORTION OF N } \\
\text { MODIFIED BY } \text { ARM }\end{array}$} \\
\hline Teufel & $2961(4178)$ & $180(236)$ & $236 / 4178$ & $\mathbf{5 . 6 5 \%}$ \\
\hline Kerl & $2477(4102)$ & $102(160)$ & $160 / 4102$ & $\mathbf{3 . 9 0 \%}$ \\
\hline Seele & $11963(13713)$ & $106(133)$ & $133 / 13713$ & $\mathbf{0 . 9 7 \%} \%$ \\
\hline Leut & $20886(28442)$ & $186(246)$ & $246 / 28442$ & $\mathbf{0 . 8 6 \%}$ \\
\hline Junge & $10281(14840)$ & $91(120)$ & $120 / 14840$ & $\mathbf{0 . 8 0 \%}$ \\
\hline Mädchen & $13621(18162)$ & $88(105)$ & $105 / 18162$ & $\mathbf{0 . 5 8 \%}$ \\
\hline Kind & $45548(55582)$ & $234(290)$ & $290 / 55582$ & $\mathbf{0 . 5 2} \%$ \\
\hline Mann & $55811(74448)$ & $190(255)$ & $255 / 74448$ & $\mathbf{0 . 3 4} \%$ \\
\hline Frau & $53645(71575)$ & $179(237)$ & $237 / 71575$ & $\mathbf{0 . 3 3 \%}$ \\
\hline Mensch & $66063(81063)$ & $169(234)$ & $234 / 81063$ & $\mathbf{0 . 2 9} \%$ \\
\hline Land & $58333(64997)$ & $159(180)$ & $180 / 64997$ & $\mathbf{0 . 2 8 \%}$ \\
\hline
\end{tabular}

Table 6: The 11 most frequent nominal collocates of arm 'poor' in DWDS-Kerncorpus (Land has been added to show that only the first ten are human nouns). ${ }^{26}$

25 With an interval of maximally two words between stakkels and the common noun.

26 Other nominal collocates of the adjective arm among the first 25 items listed are: Schlucker, Sünder, Mama, Mutter, Luder, Hund, Volk and Bevölkerung. 
Subsequently all the cases in which arm does not occur as an adnominal modifier were removed from the sample; further, all the examples of non-attitudinal arm were separated from the instances in which the speaker or writer used arm to express a certain degree of sympathy for the referent. ${ }^{27}$ Here are some examples of cases that were removed:

$\begin{array}{lllll}\text { (1+) Wie arm müssen } & \text { diese Menschen } & \text { sein, ...! } \\ \text { how poor must } & \text { these people } & \text { be, ... }\end{array}$

'How poor these people must be, ...!' [arm is not a modifier]

(20) die

die reiche Frau wird durch die Schiebungen eines Spekulanten
the rich woman becomes by the shadydeals of a speculator
eine arme Frau.

a poor woman

'the rich woman becomes a poor woman because of the shady deals of a speculator.'

(21) Denn diese Regierung war arm an Männern von hohem Ansehen und... for this government was poor in men of high regard and...

'For this government contained too few men of high regard and ...'

The separation of attitudinal and non-attitudinal occurrences of arm was done by a native speaker of German and turned out to be a relatively straightforward procedure in the great majority of the cases, as the context usually contained one or more disambiguating elements. ${ }^{28}$ Here are, for example, some of the words that signaled the occurrence of nonattitudinal $\mathrm{arm}:{ }^{29}$

(22a) Frau: Geld, Ehrenschuld, Erwerbsquelle, Luxus, reich, Bettelkinder

(22b) Junge: Reichtum, Schulgeld, Bank, Kolleggeld, Pfennig, Mark

(22c) Kind: Geld, Notstand, Unterstützung, schenken

The last row of Table 7 ('Proportion of non-attitudinal $\mathrm{arm}+N$ ') specifies the number of occurrences in which arm means 'having little money or possessions'. Interestingly arm in the sense of ohne Nutzgehalt, kärglich 'without content or real substance', as in (21), was only attested with the collocate Mann and only in this particular predicative construction (arm an ...; three tokens in all).

27 Both in Dutch and in German attittudinal arm can occur with another modifier (der arme, schwache Mann 'the poor, weak, man'), but they cannot be coordinated a non-attitudinal adjective. For example, the adjective arm in (Dutch) de zwakke en arme man 'the weak and poor man' or de arme en zwakke man 'the poor and weak man' can only mean that the man is weak and has inadequate means.

28 The adjective reich 'rich' is highest on the list of all collocates of arm.

29 The noun (or rather lemma) Kerl only occurred once with non-attitudinal arm: “ ... so gibt es andererseits Mädchen genug, die sich um keinen Preis verkaufen möchten, die lieber einen armen Kerl heiraten, dem sie von Herzen zugetan sind, ..." 


\begin{tabular}{|c|c|c|c|c|}
\hline N [LEMMA] & $\begin{array}{l}\text { NUMBER } \\
\text { OF TOKENS } \\
\text { OF N }\end{array}$ & $\begin{array}{l}\text { NUMBER OF } \\
\text { OCCURRENCES } \\
\text { OF ARM + N } \\
\text { (ADJUSTED) }\end{array}$ & $\begin{array}{c}\text { PROPORTION OF } \\
\text { ATTITUDINAL } \\
A R M+\mathbf{N}\end{array}$ & $\begin{array}{c}\text { PROPORTION OF } \\
\text { NON-ATTITUDINAL } \\
A R M+N\end{array}$ \\
\hline Seele & 11963 & 105 & $\begin{array}{lll}105 / 105 & \mathbf{1 0 0} & \%\end{array}$ & \\
\hline Teufel & 2961 & 172 & $\begin{array}{lll}172 / 172 & \mathbf{1 0 0} & \% \\
\end{array}$ & {$[37 / 172 \quad 21.6 \%]$} \\
\hline Kerl & 2477 & 100 & $\begin{array}{lll}99 / 100 & \mathbf{9 9} & \%\end{array}$ & $1 / 100 \quad 1 \%$ \\
\hline Frau & 53645 & 170 & $156 / 170$ & $14 / 170$ \\
\hline Mensch & 66063 & 142 & $125 / 142 \quad \mathbf{8 8} \quad \%$ & $17 / 142$ \\
\hline Junge & 10281 & 89 & $87.6 \%$ & $12.4 \%$ \\
\hline Kind & 45548 & 200 & $151 / 200$ & $49 / 200$ \\
\hline Mädchen & 13621 & 85 & $75.3 \%$ & $24.7 \%$ \\
\hline Mann & 55811 & 183 & $54.1 \%$ & $84 / 183$ \\
\hline Leut & 20886 & 178 & $20.9 \%$ & $144 / 182$ \\
\hline
\end{tabular}

Table 7: The 10 most frequent collocates of $A R M$ in DWDS-Kerncorpus (see also note 29).

The data in Table 7 also show that armer Teufel and arme Seele are actually frozen expressions (idioms), which is confirmed by the fact that in these expressions attitudinal arm never occurs with another adjective. ${ }^{30}$

The ten most frequent collocates of stakkels and attitudinal arm are rather similar in that both lists consist of nouns denoting entities that language users can identify with easiest: fellow human beings (only rarely an attitudinally modified NP refers to the speaker or writer him/herself; see section 4.1). Both in Danish and in German, however, there is one exception among the most frequently collocating nouns: $d y r$ 'animal' in the case of stakkels and Land 'country, nation' in the case of arm (but recall that Land is actually just outside the top ten of most frequent nominal collocates; cf. Table 6).

Stakkels and attitudinal arm can also occur with other noun attributes, of course (such cases were not taken into account in Table 3 and 4): ${ }^{31}$

$$
\begin{array}{lll}
\text { stakkels rig } & \text { pige } \\
\text { poor rich } & \text { girl } \\
\text { 'poor rich girl' } &
\end{array}
$$

30 When arm modifies Seele 'soul' it always expresses sympathy for the referent of the NP. However, when arm modifies Teufel 'devil' in contexts where reference is made to poor financial or material circumstances, it can be difficult to separate attitudinal from non-attitudinal usage, as in: Ich bin auch in früheren Jahren mehrfach in Geldnot gewesen; aber da war ich sozusagen ein ehrlicher armer Teufel 'I have also experienced a shortage of money in the past; but then I was, one could say, an honest poor devil'. So as to account for the number of more or less ambiguous occurrences of arm + Teufel, the last cell in the row after Teufel indicates how often this particular combination occurred in the context of verbs such as sparen 'to save' or bezahlen 'to pay', nouns like Schuld 'debt', Rechnung 'bill', Bankier 'banker', Geld 'money' or adjectives like reich 'rich' or arbeitslos 'unemployed'.

31 Actually, DWDS-Kerncorpus contains one instance of Teufel with another adjective besides arm (from Bernhard Grzimek (1954): Kein Platz für wilde Tiere. München: Kindler, p. 275): "Es war die Nummer unseres Lastwagens, der die Tiere beförderte. Wir überlegten, dann meinte Marinos, es seien arme schwarze Teufel und man müßte ihnen anstandshalber helfen." Notice furthermore that it does not seem possible to modify attitudinal arm itself in Dutch or German. For example, een zeer arm kind 'a very poor child' can only mean 'having little money or possessions'. Instead speakers of Dutch use the adjective zielig 'pitiful', as in e.g. een erg zielig kind 'a very pitiful child'. 
(24) den stakkels, lille danske pige the poor little Danish girl 'the poor little Danish girl'

The most frequent adjectival collocates of stakkels are lille 'small, little', unge 'young', gamle 'old', and uskyldige 'innocent'. Here are some examples from the corpus (here, too, we used an interval of maximum two words):

(25) nogle stakkels, uskyldige dommere some poor innocent judges 'some poor innocent judges'

(26) en stakkels lille fugl a poor little bird 'a poor little bird'

According to Butler (2008, p. 250), one should actually expect to find adjectives like 'young', 'small' or 'old' co-occurring with an 'attitudinal modifier' such as stakkels or arm, since "... all of [them], significantly, refer to a property which confers vulnerability, through either age (low or high), or small size". In other words these modifiers are also used to express the speaker's sympathy for the referent. Furthermore, the fact that stakkels has these adjectives as its collocates, illustrates the point we made earlier, namely that attitudinal modification affects the grammar of the entire phrase (lexical choice, syntax, morphology, prosody etc.).

In the German corpus, attitudinal arm is used together with a similar set of adjectives, including, for example, jung 'young', klein 'small', verstoßen 'abandoned', heimatlos 'homeless', hilfslos 'helpless' and müde 'tired'.

$$
\begin{aligned}
& \text { Armes, armes, kleines, verlassenes Ding! } \\
& \text { Poor poor little abandoned } \\
& \text { 'Poor, poor little abandoned creature!' }
\end{aligned}
$$

Example (27) also illustrates another property of attitudinal arm: in quite a few cases (approximately 100 instances in DWDS-Kerncorpus) arm collocates with itself: ${ }^{32}$

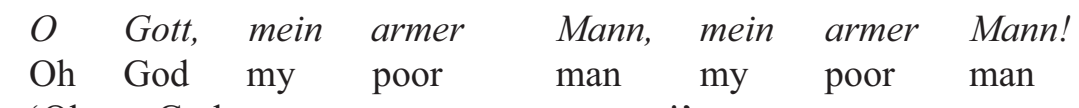

Mein armes, armes Kind!
my poor poor child
'My poor, poor child'

The same can be said about Danish stakkels, as some 30 instances of repetition were attested in KorpusDK:

Stakkels, stakkels dem! poor poor them

'Poor, poor them!'

(31) Stakkels lille Gris, stakkels lille Gris poor little Pig poor little Pig 'Poor little Pig, poor little Pig'

\footnotetext{
32 In this collocation query up to five words could appear between two instances of arm.
} 
In sum, the pool from which nouns and adjectives in attitudinally modified NPs are selected is rather small and this, together with other grammatical properties of attitudinally modified NPs, is something that should be accounted for in any structural-functional grammatical theory in the sense of Butler (2003).

\subsection{Syntactic environments}

Section 3 showed that the various subtypes of non-attitudinal functional modifier categories strongly correlate with positive or negative values for certain grammatical parameters (Modification, Predication, Reference). The current section demonstrates that NPs marked for attitudinal modification also come with a number of grammatical characteristics, as was in fact already seen in example (2). Even though the properties discussed in this section reflect formal tendencies rather than necessary and sufficient features of attitudinally modified NPs, they still provide supporting evidence for the main claim of this paper that functional categories are grammatical entities that deserve a place in any grammatical theory that aims to give a satisfactory account of the linguistic facts.

Here we highlight one particular property of attitudinally modified NPs that contain the modifiers stakkels or arm: the fact that these NPs have a tendency to be expressed (more often than NPs without an attitudinal 'overlay') as INDEPENDENT UNITS, i.e. as an exclamation or form of address, as an appositional phrase following a cross-referencing pronoun or as a dislocated phrase. Occurrences of attitudinally modified independent NPs were divided in four subcategories, as illustrated by the following examples (notice that in (32) stakkels pige is not used as a form of address, but rather as an afterthought). ${ }^{33}$

$$
\begin{array}{llllll}
\text { Det } & \text { er } & \text { forfcerdeligt } & \text {..., stakkels } & \text { pige. } & \text { INDEFINITE NP } \\
\text { that } & \text { is } & \text { terrible } & \ldots, \text { poor } & \text { girl } &
\end{array}
$$
'That's terrible ..., poor girl'

$\begin{array}{lll}\text { De stakkels } & \text { børn. } & \text { Definite NP } \\ \text { the poor } & \text { children } & \\ \text { 'The poor children.' } & \end{array}$

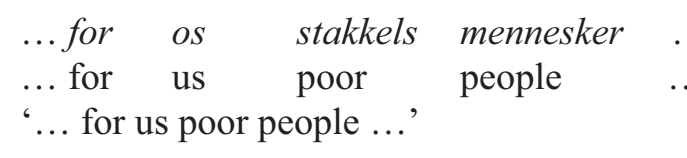

(35) Min stakkels mor. my poor mother

Appositional: [[PRo] [NP]]

'MY POOR N' 'My poor mother.'

The relevance of parameter ' \pm Independent NP' can only be appreciated, of course, when attitudinally modified independent NPs are compared with independent NPs without some attitudinal overlay. For this purpose we investigated the syntactic environment of independent NPs with other head nouns (like Kleid 'dress') and other adjectival modifiers (such as schön 'pretty, handsome, beautiful, lovely, etc. and nett 'cute, pretty, good, nice, etc.').

33 Cf. Dik (1997 Part 2, Chapter 17) on the phenomenon of Extra Clausal Constituents (ECC's); see also Connolly (2008) on freestanding NPs in documents. 


\begin{tabular}{|l|cc|cc|}
\hline & \multicolumn{2}{|c|}{$\begin{array}{c}\text { Proportion of } \\
\text { independent NPs } \\
\text { headed by } \text { Frau }\end{array}$} & $\begin{array}{c}\text { Proportion of } \\
\text { independent NPs } \\
\text { headed by } \text { Kleid }\end{array}$ \\
\hline attitudinal $\mathrm{arm}($ lemma) & $24 / 156$ & $\mathbf{1 4 . 7} \%$ & $0 / 1$ & $\mathbf{0} \%$ \\
\hline schön $($ lemma) & $16 / 338$ & $\mathbf{4 . 7} \%$ & $0 / 57$ & $\mathbf{0} \%$ \\
\hline nett $($ lemma) & $0 / 14$ & $\mathbf{0} \%$ & $0 / 1$ & $\mathbf{0} \%$ \\
\hline
\end{tabular}

Table 8: Proportion of INDEPENDENT NPs with adjectives (attitudinal) arm, schön or nett and nouns Frau or Kleid

Table 8 indicates that almost 15 percent of the attitudinally modified NPs with the constituents arme and Frau are independent in the sense defined above (see also Table 10), but this is the case for only 4.7 percent of the NPs with the same head noun modified by $s$ shön $^{34}$. The main reason we find schöne Frau in independent NPs is that the adjective schön is also used in forms of address (e.g. Nein, nein, schönes Mädchen, laß deine Hän$d e$ ! 'No, no, dear girl, hands off!'), a function it shares with attitudinally modified NPs (see (36) and (37)). A phrase headed by a non-human (or perhaps better: non-animate) noun is not normally used in a form of address, which explains why we do not find a single example of an independent NP with, for example, Kleid ${ }^{35}$ 'dress' modified by adjectives arm or schön. ${ }^{36}$ For the sake of completeness, we also checked if the corpus contains independent NPs with Frau or Kleid modified by an adjective that normally should not appear in a form of address, viz. nett. As expected, the corpus contains no such cases.

When an attitudinally modified NP is used as a form of address, there is a mismatch between pragmatics and morphosyntax in that an address is pragmatically definite (the referent is also the addressee, i.e. a familiar or identifiable entity), but the independent NP typically lacks an overt definite determiner (e.g. definite article or demonstrative). This means that what could be regarded as an indefinite NP from a formal perspective, should count as a definite NP from a pragmatic perspective.

Armer Kerl, hast du das gewollt?
poor guy have you that wanted?
'Poor guy, is that what you wanted?'

"Stakkels pige", hørte hun en stemme.
poor girl, heard she a
"“Poor girl", she heard a voice say."

This is accounted for in Table 9 and 10 in the following way. The bracketed number in the column 'Definite NP' indicates the number of cases in which the attitudinally modified independent NP was used as a direct address. ${ }^{37}$ Notice that in Danish this only concerns

34 For the sake of convenience we used no interval in the case of adjectives (lemmas) schön and nett in combination with the nouns (lemmas) Frau and Kleid.

35 Here are the two examples of armes Kleid and nettes Kleid: (i) “... laß mir das arme Kleid meines Ordens!" (Schneider 1938), (ii) "Wie bei anderen Tanzveranstaltungen wird man sich auch hier einen guten Anzug und ein nettes Kleid anziehen.” (Smolka 1947).

36 Even though it could occur in exclamations of the type 'What a beautiful dress!'.

37 This includes both proper addresses (where the address is meant to heard by the addressee) and quasi addresses, i.e. forms of address that are uttered but not necessarily heard or understood by the addressee, as in Stakkels dyr, mumlede han 'Poor animal, he muttered'. 
the three most frequently attested nouns that appear in independent NPs with stakkels (Table 9).

\begin{tabular}{|c|c|c|c|c|c|}
\hline $\begin{array}{c}\mathrm{N} \\
\text { [lemma] }\end{array}$ & $\begin{array}{c}\text { Indefinite } \\
\text { NP }\end{array}$ & $\begin{array}{l}\text { Definite } \\
\text { NP }\end{array}$ & $\begin{array}{l}\text { Appositional: } \\
\text { [[pro] [NP]] }\end{array}$ & $\begin{array}{l}\text { 'my poor } \\
\mathbf{N} \text { ' }\end{array}$ & $\begin{array}{c}\text { Proportion of } \\
\text { INDEPENDENT NPS } \\
\text { with stakkels } \\
\end{array}$ \\
\hline mor & 7 & $2(2)$ & & 1 & $10 / 17 \quad \mathbf{5 8 . 8} \%$ \\
\hline dreng & 6 & $1(1)$ & & 1 & $8 / 23 \quad 34.8 \%$ \\
\hline pige & 11 & $4(1)$ & & 1 & $16 / 47 \quad 34 \quad \%$ \\
\hline fyr & 2 & & & & $\begin{array}{lll}2 / 8 & 25 & \% \\
\end{array}$ \\
\hline kone & 2 & & & & $2 / 9 \quad 22.2 \%$ \\
\hline mand & 12 & 2 & $1(1 \times 1 P L)$ & & $15 / 70 \quad 21.4 \%$ \\
\hline barn & 5 & 4 & & & $9 / 47 \quad 19.1 \%$ \\
\hline menneske & 3 & 2 & $3(2 \times 1 \mathrm{PL}, 1 \times 2 \mathrm{PL})$ & & $8 / 55 \quad 14.5 \%$ \\
\hline$d y r$ & & $1(1)$ & & & $1 / 22 \quad 4.5 \%$ \\
\hline kvinde & & & & & $\begin{array}{ll}0 & \% \\
\end{array}$ \\
\hline
\end{tabular}

Table 9: Independent noun phrases with stakkels in KorpusDK.

Here are examples involving attitudinal arm:
(38) So
$\begin{array}{ll}\text { So } & \text { eine } \\ \text { such } & \text { a }\end{array}$
arme, junge Frau,
sagte sie
mitleidig.
INDEFINITE NP
'Such a poor, young woman, she said pityingly'

$$
\begin{aligned}
& \text { Der arme Junge! } \\
& \text { the poor boy } \\
& \text { 'The poor boy!' }
\end{aligned}
$$
Ach, wir
armen, armen
oh we poor poor
Menschen!
Appositional: [[PRO] [NP]]
'Oh, we poor poor people!'
people

The following example displays both the appositional construction $\left(\left[[\text { Dich }]_{\mathrm{NP}}[\right.\right.$ mein armes Kind $\left.]_{\mathrm{NP}}\right]_{\mathrm{NP}}$ ) and an instance of the 'my poor N' pattern:

\begin{tabular}{|c|c|c|c|c|c|}
\hline $\begin{array}{c}\mathrm{N} \\
\text { [lemma] }\end{array}$ & $\begin{array}{c}\text { Indefinite } \\
\text { NP }\end{array}$ & $\begin{array}{c}\text { Definite } \\
\text { NP }\end{array}$ & $\begin{array}{l}\text { Appositional: } \\
\text { [[pro] [NP]] }\end{array}$ & $\begin{array}{c}\text { 'my } \\
\text { poor } \mathrm{N} \text { ' }\end{array}$ & $\begin{array}{l}\text { Proportion of } \\
\text { INDEPENDENT } \\
\text { NPS with } \\
\text { attitudinal } \mathrm{arm}\end{array}$ \\
\hline Junge & 5 & $18(6)$ & $4(2 \times 1 \mathrm{Sg}, 2 \times 2 \mathrm{Sg})$ & 1 & $28 / 89 \quad 31.5 \%$ \\
\hline Kerl & 10 & $17(6)$ & $4(1 \times 1 \mathrm{SG}, 1 \times 2 \mathrm{Sg}, 2 \times 2 \mathrm{Pl})$ & & $31.3 \%$ \\
\hline Kind & 2 & $26(15)$ & $8(1 \times 1 \mathrm{Sg}, 7 \times 2 \mathrm{Sg})$ & 19 & $55 / 200 \quad \mathbf{2 7 . 5} \%$ \\
\hline Leut & 2 & $5(1)$ & $3(3 \times 1 \mathrm{Pl})$ & & $10 / 38 \quad \mathbf{2 6 . 3} \%$ \\
\hline Frau & 5 & $13(3)$ & $3(2 \times 1 \mathrm{Sg}, 2 \mathrm{Pl})$ & 2 & $23 / 156 \quad 14.7 \%$ \\
\hline Mann & 4 & $12(6)$ & $9(5 \times 1 \mathrm{Sg}, 4 \times 2 \mathrm{Sg})$ & 2 & $27 / 183 \quad 14.7 \%$ \\
\hline Teufel & 10 & $9(1)$ & $6(1 \times 1 \mathrm{Sg}, 1 \times 2 \mathrm{Sg}, 2 \times 1 \mathrm{Pl}, 2 \times 2 \mathrm{Pl})$ & & $25 / 172 \quad 14.5 \%$ \\
\hline Mensch & 2 & $5(1)$ & $10(1 \mathrm{Sg}, 2 \times 2 \mathrm{Sg}, 7 \times 1 \mathrm{Pl})$ & & $17 / 142 \quad 12 \quad \%$ \\
\hline Mädchen & 2 & 4 & $3(1 \mathrm{Sg}, 1 \mathrm{Pl}, 1 \times 2 \mathrm{Sg})$ & & $9 / 85 \quad \mathbf{1 0 . 6} \%$ \\
\hline Seele & & $6(2)$ & & & $9 / 105$ \\
\hline
\end{tabular}

(41) Und ich mu $\beta$ Dich, mein armes Kind, nun bald verlassen.
and 'And I must leave you, my poor child, soon now.'

Table 10: Independent noun phrases with attitudinal arm in DWDS-Kerncorpus. ${ }^{38}$

38 2. Sg covers both occurrences of $d u$ and (polite) Sie. 
Even though we are concerned with the same phenomenon in Danish and German, i.e. attitudinally modified noun phrases, we can see some interesting differences. In Danish INDEFINITE independent NPs appear to form the preferred syntactic environment for 'attitudinal modifiers' like stakkels, with an exceptionally high score of almost 60 percent for stakkels mor 'poor mother'. By contrast, attitudinal arm tends to appear more often in independent NPs that are DEFINITE, which seems partly due to the fact that in German the attitudinally modified NP is used as a form of address more often than in Danish. There is also a remarkable difference with regard to the proportion of attitudinally modified NPs that are in an appositional relation with a preceding personal pronoun (see examples (34) and (40)). The Danish corpus produced only four examples involving its dedicated 'attitudinal modifier' stakkels (invariably in an NP with plural reference), whereas the German corpus has instances of this construction for each of the ten most frequent nominal collocates of attitudinal arm in NPs (with singular or plural reference). Notice, furthermore, that neither the Danish nor the German corpus contains an appositional construction with a third person pronoun (cf. section 4.1 .1 on the combination stakkels/arm + personal pronoun).

Let us finally turn to the fourth parameter, the presence of a first person singular possessive pronoun ('my') in independent attitudinally modified NPs. In the case of Danish, there are only three such cases (one token for each of the three most frequent nominal collocates: mor, drenge, pige), and in German we also see that only in the case of a handful nominal collocates (Junge, Kind, Frau, Mann) the speaker occasionally also refers to him or herself. The only exception is Kind, where in almost 35 percent of the cases (19 out of 55 occurrences) the first person possessive pronoun is used.

In this section we have shown that there are interesting differences and similarities between dedicated 'attitudinal modifiers' like Danish stakkels on the one hand and non-dedicated modifiers such as German arm on the other, but a detailed investigation of these and any other properties would clearly be beyond the scope of the current paper. Here we will conclude with the observation that attitudinally modified NPs in Danish and German occur in syntactic environments where neutral NPs appear less frequently or not at all.

\section{Conclusion}

Some linguists assume that there is a straightforward relationship between the form and the function of a linguistic expression. ${ }^{39}$ This is clearly wrong since a linguistic form or construction, like many other entities, can have various functions. Moreover, a recent study claims that the multifunctional use of objects is uniquely associated with human behavior. ${ }^{40}$ With regard to the relationship between morphosyntactic FORM and coded MEANING (semantics), it has been argued that it is economic for languages to employ polysemous words (up to a point, of course), i.e. words that have several related meanings (Croft 2003, p. 101-109). ${ }^{41}$ Similar things can be said about the relationship between FORM and FUNCTION

39 Cf. McCawley’s (1985, p. 675) review of Newmeyer (1983): “... functional accounts need not recognize such a thing as THE function of anything”. See also Dik (1986, p. 17-18) on what constitutes a functional explanation in grammatical theory.

40 Cf. Hauser (2009, p. 34): "Animal tools, in contrast [with human tools - JR] are composed of a single material, designed for just a single function and never used for other functions."

41 "In the simplest cases, lexical items are pairings of phonological forms with individual concepts. But such simple cases are rare exceptions. Polysemy is the norm. Most words have a number of systematically related meanings" (Lakoff and Johnson 1999, p. 499; see also Dingfang 2009). 
(pragmatics): multifunctional forms also exemplify paradigmatic economy in that they minimize the number of forms and constructions used in actual discourse. Obviously, if all the linguistic units in a language were multifunctional, this would make verbal communication practically impossible or least an extremely cumbersome and inefficient affair. Hence we may expect languages, or rather language users, to put a limit on the degree of polysemy and multi-functionality in a language, so as to ensure that languages can maintain their primary function: to serve as an efficient system of verbal or signed communication (cf. Hengeveld et al. 2004). So what we actually see is that languages allow for a certain amount of multi-functionality, but not so much that it would stand in the way of successful communication. This does in no way imply that languages shouldn't also make use of dedicated or specialized elements. Indeed, we may expect to find in any language units that are fairly multifunctional (such as Dutch adnominal PPs with van 'of'; section 3), as well as units that are basically mono-functional (such as Danish stakkels 'poor'; section 4).

In sum, in this paper I have argued (i) that functional categories should be part of any grammatical theory that strives for (descriptive, explanatory, typological, pragmatic, psychological etc.) adequacy and (ii) that modifiers (and other linguistic forms and constructions) can be felicitously categorized in functional (instrumental) terms. Moreover, I have shown that members of the same formal category (PP) can have different grammatical properties depending on the function they have in an actual linguistic expression (section 3 ) and that some forms have a very specialized function, which comes with its own set of grammatical properties (section 4). In other words, both in the case of multi-functional and mono-functional linguistic units we see that membership of a functional category comes with a set of distinct grammatical features.

\section{References}

Biber, Douglas/Johansson, Stig/Leech, Geoffrey/Conrad, Susan/Finegan, Edward (1999): Longman Grammar of Spoken and Written English. Harlow: Pearson Education Limited.

Broschart, Jürgen (1997): Why Tongan does it differently: categorial distinctions in a language without nouns and verbs. In: Linguistic Typology 1-2, S.123-165.

Butler, Christopher S. (2003): Structure and Function: A Guide to Three Major Structural-Functional Theories. Part 1: Approaches to the Simplex Clause. Amsterdam and Philadelphia: Benjamins.

Butler, Christopher S. (2008): Interpersonal meaning in the noun phrase. In: García Velasco, Daniel/Rijkhoff, Jan (eds.): The Noun Phrase in Functional Discourse Grammar. Berlin/New York: de Gruyter. S. 221-261.

Clark, Herbert H./Clark, Eve V. (1977): Psychology and Language: An Introduction to Psycholinguistics. New York: Harcourt Brace Jovanovich.

Connolly, John H. (2008): Freestanding noun phrases within documents: a pragmatic approach based on Functional Discourse Grammar. In: García Velasco, Daniel/Rijkhoff, Jan (eds.): The Noun Phrase in Functional Discourse Grammar. Berlin/New York: de Gruyter. S. 263-285.

Coseriu, Eugenio (1977): El hombre y su lenguaje. Estudios de tería y metodología lingüística. Madrid: Gredos.

Croft, William (1991): Syntactic Categories and Grammatical Relations: The Cognitive Organization of Information. Chicago: University of Chicago Press.

Croft, William (2003): Typology and Universals [2 $2^{\text {nd }}$ ed.]. Cambridge: Cambridge University Press.

Dik, Simon C. (1986): On the notion ‘functional explanation’. In: Belgian Journal of Linguistics 1, S. 11-52. 
Dik, Simon C. (1997): The Theory of Functional Grammar ( $2^{\text {nd }}$ revised edition, edited by Kees Hengeveld). Part 1: The Structure of the Clause. Part 2: Complex and Derived Constructions. Berlin/New York: de Gruyter.

Dingfang, Shu (2009): Cognitive approaches to lexical semantics. In: Language and Linguistics Compass 3-1, S. 314-337.

Dixon, Robert M.W. (1982): Where have all the adjectives gone? and other essays in semantics and syntax. Berlin/New York: de Gruyter.

Dryer, Matthew S. (2008): Order of adjective and noun. In: Haspelmath, Martin/Dryer, Matthew S./Gil, David/Comrie, Bernard (eds.): The world atlas of language structures online, Chapter 87. München: Max Planck Digital Library. http://wals.info/feature/87 (31 December 2008).

Everett, Daniel L. (2005): Cultural constraints on grammar and cognition in Pirahã: another look at the design features of human language. In: Current Anthropology 46, S. 621-634.

Gil, David (2009): Genitives, adjectives, and relative clauses. In: Haspelmath, Martin/Dryer, Matthew S./ Gil, David/Comrie, Bernard (eds.): The world atlas of language structures online, Chapter 60. München: Max Planck Digital Library. http://wals.info/feature/60 (13 August 2009).

Greenberg, Joseph H. (1966): Some universals of grammar with particular reference to the order of meaningful elements. In: Greenberg, Joseph H. (ed.): Universals of Language ( $2^{\text {nd }}$ edition). Cambridge: MIT. S. 73-113.

Gunkel, Lutz/Zifonun, Gisela (2008): Constraints on relational-adjective noun constructions: a comparative view on English, German and French. In: Zeitschrift für Anglistik und Amerikanistik 56, S. 283-302.

Gunkel, Lutz/Zifonun, Gisela (2009): Classifying modifiers in common names. In: Word Structure 2-2, S. 205-218.

Firbas, Jan (1992): Functional Sentence Perspective in Written and Spoken Communication. Cambridge: Cambridge University Press.

Halliday, Michael/Kirkwood, Alexander (2004): An Introduction to Functional Grammar (3 ${ }^{\text {rd }}$ ed.). London: Arnold.

Haspelmath, Martin (2007): Pre-established categories don't exist: Consequences for language description and typology. In: Linguistic Typology 11-1, S. 119-132.

Hauser, Marc (2009): The mind. In: Scientific American, September 2009, S. 30-37.

Heine, Bernd (1997): Possession: Cognitive Sources, Forces, and Grammaticalization. Cambridge: Cambridge University Press.

Hengeveld, Kees/Rijkhoff, Jan/Siewierska, Anna (2004): Parts-of-speech systems and word order. In: Journal of Linguistics 40-3, S. 527-570.

Hengeveld, Kees/Rijkhoff, Jan (2005): Mundari as a flexible language. In: Linguistic Typology 9-3, S. 406-431.

Hengeveld, Kees/Mackenzie, J. Lachlan (2008): Functional Discourse Grammar: A typologically-based theory of language structure. Oxford: Oxford University Press.

Hockett, Charles F. (1958): A Course in Modern Linguistics. New York: The Macmillan Company.

Huddleston, Rodney/Pullum, Geoffrey (2002): The Cambridge Grammar of the English Language. Cambridge: Cambridge University Press.

Kroeger, Paul R. (2005): Analyzing grammar. Cambridge: Cambridge University Press.

Lehmann, Christian (1984): Der Relativsatz: Typologie seiner Strukturen, Theorie seiner Funktionen, Kompendium seiner Grammatik. Tübingen: Narr.

Lehmann, Christian (2008): Roots, stems and word classes. In: Studies in Language 32-3, S. 546-567. 


\section{Jan Rijkhoff}

Lakoff George/Johnson, Mark (1999): Philosophy in the Flesh. The embodied mind and its challenge to western thought. New York: Basic Books.

Lyons, John (1982): Deixis and subjectivity: Loquor, ergo sum? In: Jarvella, Robert J./Klein, Wolfgang (eds.): Speech, Place, and Action: Studies in Deixis and Related Topics. New York: Wiley. S. 101-124.

Lyons, John (1994): Subjecthood and subjectivity. In: Yaguello, Marina (ed.): Subjecthood and subjectivity: The Status of the Subject in Linguistic Theory. Paris: Ophrys. S. 9-17.

McCawley, James D. (1985): Review of Frederick J. Newmeyer (1983), Grammatical theory: Its limits and possibilities. In: Language 61-3, S. 668-679.

Mosel, Ulrike/Hovdhaugen, Even (1992): Samoan reference grammar. Oslo: Universitetsforlaget AS.

Newmeyer, Frederick J. (2007): Linguistic typology requires crosslinguistic formal categories. In Linguistic Typology 11-1, S. 133-157.

Nordhoff, Sebastian (2009): Jack-of-all-trades: the Sri Lanka Malay flexible adjective. Manuscript, Dept. of Linguistics, University of Amsterdam.

Rijkhoff, Jan (2004): The Noun Phrase. Oxford: Oxford University Press [expanded paperback edition of 2002 hardback publication].

Rijkhoff, Jan (2008a): Layers, levels and contexts in Functional Discourse Grammar. In: García Velasco, Daniel/Rijkhoff, Jan (eds.): The Noun Phrase in Functional Discourse Grammar. Berlin/New York: de Gruyter. S. 63-115.

Rijkhoff, Jan (2008b): Layering and iconicity in the noun phrase: descriptive and interpersonal modifiers. In: Linguistics 46-4, S. 789-829.

Rijkhoff, Jan (2008c): Synchronic and diachronic evidence for parallels between noun phrases and sentences. In: Josephson, Folke/Söhrmann, Ingmar (eds.): Interdependence of Diachronic and Synchronic Analyses. Amsterdam/Philadelphia: Benjamins. S. 13-42.

Rijkhoff, Jan (2009a): On the (un)suitability of semantic categories. In: Linguistic Typology 13-1, S. 95-104.

Rijkhoff, Jan (2009b): On the co-variation between form and function of adnominal possessive modifiers in Dutch and English. In: McGregor, William B. (ed.): The Expression of Possession. Berlin/ New York: de Gruyter. S. 51-106.

Rijkhoff, Jan (2010): Rara and grammatical theory. In: Wohlgemuth, Jan/Cysouw, Michael (eds.): Rethinking Universals: How rarities affect linguistic theory (Empirical Approaches to Linguistic Typology (EALT) 45). Berlin/New York: de Gruyter. S. 232-240.

Sampson, Geoffrey (1980): Schools of linguistics: competition and evolution. London: Hutchinson.

Sasse, Hans-Jürgen (1993): Syntactic categories and subcategories. In: Jacobs, Joachim et al. (eds.): Syntax: an international handbook of contemporary research [2 volumes]. Berlin: de Gruyter. S. 646-686.

Seiler, Hansjakob (1978): Determination: a functional dimension for interlanguage comparison. In: Seiler, Hansjakob (ed.): Language universals: Papers from the Conference at Gummersbach/Cologne, Germany Oct. 3-8, 1976. Tübingen: Narr. S. 301-328.

Seiler, Hansjakob (1983): Possession as an operational dimension of language. Tübingen: Narr.

Seiler, Hansjakob (1985): Kategorien als fokale Instanzen von Kontinua, gezeigt am Beispiel der Nominalen Determination. In: Schlerath, Bernfried/Ritter, Veronica (eds.): Grammatische Kategorien: Funktion und Geschichte. Wiesbaden: Reichert. S. 435-448.

Stassen, Leon (1986): The comparative compared. In: Journal of Semantics 3, S. 143-182.

Traugott, Elizabeth Closs (2003): From subjectification to intersubjectification. In: Hickey, Raymond (ed.): Motives for Language Change. Cambridge: Cambridge University Press. S. 124-139. 
Traugott, Elizabeth Closs (In press): From ideational to interpersonal: A reassessment. In: Cuyckens, Hubert/ Davidse, Kristin/Vandelanotte, Lieven (eds.): Subjectification, intersubjectification and grammaticalization. Berlin/New York: de Gruyter.

Vries, Jan de (1997): Nederlands etymologisch woordenboek. Leiden: Brill.

Warren, Beatrice (1984): Classifying adjectives (Gothenburg Studies in English 56). Sweden: Göteborg.

Zifonun, Gisela (This issue): Possessive Attribute im Deutschen. S. 124-153.

Prof. Dr. Jan Rijkhoff

Århus University

Dept. of Linguistics

Bartholins Allé 16,3

Building 1410 (Ringgade)

DK-8000 Århus

E-Mail: linjr@hum.au.dk 